\title{
New tools and approaches to newborn screening: ready to open Pandora's box?
}

\author{
Can Ficicioglu \\ Children's Hospital of Philadelphia (CHOP), Perelman School of Medicine at the University of Pennsylvania, \\ Philadelphia, Pennsylvania 19104, USA
}

Abstract The landscape of newborn screening (NBS) is changing as new tools are developed. We must acknowledge that NBS is a very important and extraordinarily positive initiative especially for rare and serious inherited disorders; however, lessons learned from current NBS should guide the future of NBS as we enter the era of "omics" that will expand NBS for many other genetic disorders. In this article, I will first discuss new tools such as genomics and metabolomics for NBS. I will then turn to assessing how best to take advantage of new technical developments while considering the best interests of patients and the success of newborn screening.

Corresponding author:

ficicioglu@email.chop.edu

(c) 2017 Ficicioglu This article is distributed under the terms of the Creative Commons Attribution-NonCommercial License, which permits reuse and redistribution, except for commercial purposes, provided that the original author and source are credited.

Published by Cold Spring Harbor Laboratory Press

doi: $10.1101 / \mathrm{mcs} . \mathrm{a} 001842$
Inborn errors of metabolism (IEMs) are individually rare conditions, usually caused by partial or full enzyme deficiencies or transport defects. They result in either accumulation of toxic metabolites or lack of an important end product. Early diagnosis and treatment are essential for better outcomes or prevention of death. Newborn screening (NBS) for these rare disorders is an effective and important approach for early and presymptomatic diagnosis. State NBS programs routinely screen nearly 4 million newborns in the United States each year (AAP Newborn Screening Task Force 2000).

Newborn metabolic screening was started for early detection of phenylketonuria (PKU) using a bacterial inhibition assay developed by Robert Guthrie in the 1960s (Paul 1998). In the 1990s, the advent of tandem mass spectroscopy enabled screening of many more IEMs on a single blood spot. Currently, 49 IEMs are in the core and secondary NBS panels (Tables 1 and 2) and screened based on "targeted metabolomics" using tandem mass spectroscopy in the United States (Chace and Kalas 2005; American College of Medical Genetics Newborn Screening Expert Group 2006; Rinaldo et al. 2008; Janečková et al. 2012). In some NBS programs, "targeted mutation analysis" is also done as a secondary test when the NBS is abnormal for some IEMs and can confirm the presence of a disease. For example, in a case with elevated C8 level detected by NBS, the presence of two copies of c.985 G>A revealed by genetic testing confirms the diagnosis of medium-chain acyl-CoA dehydrogenase (MCAD).

The expansion of disorders included in NBS panels has led to significant benefits in the diagnosis and treatment of many diseases; at the same time, it has also led to unintended consequences such as overdiagnosis, unnecessary treatment, and parental anxiety (Tarini 2007; Wilcken 2013). The main goal of NBS is to detect newborns with severe IEMs in a presymptomatic period and start treatment as soon as possible to prevent complications such as death, mental retardation, and metabolic crisis (Wilson-Jungner Criteria) (Petros 2012). One 


\begin{tabular}{|c|c|c|c|c|c|}
\hline \multicolumn{5}{|c|}{ Metabolic conditions detectable by tandem mass spectrometry (MS/MS) } & \multirow{2}{*}{$\begin{array}{c}\begin{array}{c}\text { Metabolic } \\
\text { conditions } \\
\text { detectable by } \\
\text { other tests }\end{array} \\
\begin{array}{c}\text { Other } \\
\text { metabolic } \\
\text { disorders }\end{array}\end{array}$} \\
\hline $\begin{array}{l}\text { Fatty acid } \\
\text { oxidation defects }\end{array}$ & $\begin{array}{l}\text { Organic acid } \\
\text { disorders }\end{array}$ & $\begin{array}{l}\text { Amino acid } \\
\text { disorders }\end{array}$ & $\begin{array}{l}\text { Lysosomal } \\
\text { storage } \\
\text { disorders }^{\text {a }}\end{array}$ & $\begin{array}{l}\text { Peroxisomal } \\
\text { disorders }\end{array}$ & \\
\hline $\begin{array}{l}\text { Carnitine uptake } \\
\text { defect }\end{array}$ & Propionic acidemia & $\begin{array}{l}\text { Classical } \\
\text { phenylketonuria }\end{array}$ & Pompe & X-ALD & $\begin{array}{l}\text { Biotinidase } \\
\text { deficiency }\end{array}$ \\
\hline $\begin{array}{l}\text { Long-chain L-3 } \\
\text { hydroxyacyl-CoA } \\
\text { dehydrogenase } \\
\text { deficiency } \\
\text { (LCHAD) }\end{array}$ & $\begin{array}{l}\text { Methylmalonic } \\
\text { acidemia } \\
\text { (methylmalonyl- } \\
\text { CoA mutase) }\end{array}$ & $\begin{array}{l}\text { Argininosuccinic } \\
\text { aciduria }\end{array}$ & MPS-I & & $\begin{array}{l}\text { Classical } \\
\text { galactosemia } \\
\text { (GALT) }\end{array}$ \\
\hline $\begin{array}{l}\text { Medium-chain } \\
\text { acyl-CoA } \\
\text { dehydrogenase } \\
\text { deficiency } \\
\text { (MCAD) }\end{array}$ & $\begin{array}{l}\text { Methylmalonic } \\
\text { acidemia } \\
\text { (cobalamin } \\
\text { disorders) }\end{array}$ & $\begin{array}{l}\text { Citrullinemia, } \\
\text { type I }\end{array}$ & & & \\
\hline $\begin{array}{l}\text { Trifunctional } \\
\text { protein } \\
\text { deficiency (TFP) }\end{array}$ & Isovaleric acidemia & $\begin{array}{l}\text { Maple syrup urine } \\
\text { disease }\end{array}$ & & & \\
\hline \multirow{5}{*}{$\begin{array}{l}\text { Very long-chain } \\
\text { acyl-CoA } \\
\text { dehydrogenase } \\
\text { deficiency } \\
\text { (VLCAD) }\end{array}$} & $\begin{array}{l}\text { 3-Methylcrotonyl- } \\
\text { CoA carboxylase } \\
\text { deficiency }\end{array}$ & Homocystinuria & & & \\
\hline & $\begin{array}{l}\text { 3-Hydroxy-3- } \\
\text { methyglutaric } \\
\text { aciduria }\end{array}$ & $\begin{array}{l}\text { Tyrosinemia, } \\
\text { type I }\end{array}$ & & & \\
\hline & $\begin{array}{l}\text { Holocarboxylase } \\
\text { synthase } \\
\text { deficiency }\end{array}$ & & & & \\
\hline & $\begin{array}{c}\beta \text {-Ketothiolase } \\
\text { deficiency }\end{array}$ & & & & \\
\hline & $\begin{array}{l}\text { Glutaric acidemia } \\
\text { type I }\end{array}$ & & & & \\
\hline
\end{tabular}

aln some states other lysosomal storage disorders (LSDs) such as Krabbe, Niemann-Pick, Gaucher, and Fabry are also screened. The Missouri state laboratory uses the digital microfluidics (DMF) method to screen LSDs.

consequence of NBS is detecting patients with partial enzyme deficiencies such as partial biotinidase deficiency or DG galactosemia who may never need treatment (Ficicioglu et al. 2008). NBS also detects patients with late-onset forms of diseases such as late-onset very long-chain acyl-CoA dehydrogenase deficiency (VLCAD), which may only require treatment in adulthood. These patients are regularly referred to metabolic centers for expensive confirmatory tests, which in turn sometimes leads to unnecessary treatment, follow-up visits, anxiety for families, and an overburdened medical system.

The landscape of NBS is changing as new tools are developed. We must acknowledge that NBS is a very important and extraordinarily positive initiative especially for rare and serious inherited disorders; however, lessons learned from current NBS should guide the future of NBS as we enter the era of "omics" that will expand newborn screening for many other 


\begin{tabular}{|c|c|c|c|}
\hline \multicolumn{3}{|c|}{ Metabolic conditions detectable by tandem mass spectrometry (MS/MS) } & \multirow{2}{*}{$\begin{array}{c}\text { Metabolic } \\
\text { conditions } \\
\begin{array}{c}\text { detectable by other } \\
\text { tests }\end{array} \\
\begin{array}{c}\text { Other metabolic } \\
\text { disorders }\end{array} \\
\end{array}$} \\
\hline $\begin{array}{l}\text { Fatty acid } \\
\text { oxidation defects }\end{array}$ & $\begin{array}{l}\text { Organic acid } \\
\text { disorders }\end{array}$ & Amino acid disorders & \\
\hline $\begin{array}{l}\text { Short-chain acyl-CoA } \\
\text { dehydrogenase deficiency } \\
\text { (SCAD) }\end{array}$ & $\begin{array}{l}\text { Methylmalonic } \\
\text { acidemia with } \\
\text { homocystinuria } \\
\text { (Cbl C, D) }\end{array}$ & Argininemia & $\begin{array}{l}\text { Galactoepimerase } \\
\text { deficiency (GALE) } \\
\text { Galactokinase } \\
\text { deficiency (GALK) }\end{array}$ \\
\hline $\begin{array}{l}\text { Medium/short-chain L-3- } \\
\text { hydroxyacyl-CoA } \\
\text { dehydrogenase deficiency (M/ } \\
\text { SCHAD) }\end{array}$ & Malonic acidemia & Citrullinemia type II & \\
\hline Glutaric acidemia type II & Isobutyrylglycinuria & Hypermethioninemia & \\
\hline $\begin{array}{l}\text { Medium-chain ketoacyl-CoA } \\
\text { thiolase deficiency (MCAT) }\end{array}$ & $\begin{array}{l}\text { 2-Methylbutyryl } \\
\text { glycinuria }\end{array}$ & $\begin{array}{l}\text { Benign } \\
\text { hyperphenylalaninemia }\end{array}$ & \\
\hline $\begin{array}{l}\text { 2,4 Dienoyl-CoA reductase } \\
\text { deficiency }\end{array}$ & $\begin{array}{l}\text { 3-Methylglutaconic } \\
\text { aciduria }\end{array}$ & $\begin{array}{l}\text { Biopterin defect in } \\
\text { cofactor biosynthesis }\end{array}$ & \\
\hline $\begin{array}{l}\text { Carnitine palmitoyltransferase } \\
\text { type I deficiency (CPT 1A) }\end{array}$ & $\begin{array}{l}\text { 2-Methyl-3- } \\
\text { hydroxybutyric } \\
\text { aciduria }\end{array}$ & $\begin{array}{l}\text { Biopterin defect in } \\
\text { cofactor regeneration }\end{array}$ & \\
\hline $\begin{array}{l}\text { Carnitine palmitoyltransferase } \\
\text { type II deficiency (CPT 2) }\end{array}$ & & Tyrosinemia, type II & \\
\hline $\begin{array}{l}\text { Carnitine acylcarnitine } \\
\text { translocase deficiency (CACT) }\end{array}$ & & Tyrosinemia, type III & \\
\hline
\end{tabular}

genetic disorders. The study of genetics and metabolism at the global level—"omics"—is a rapidly growing field and it will inevitably impact on newborn screening in the near future. "Omic" approaches aim to analyze in a targeted or untargeted fashion the biological information carried by genes (genomics), mRNAs (transcriptomics), proteins (proteomics), and metabolites (metabolomics). It is becoming clearer that a single "omic" approach such as genomics is insufficient for completely capturing the complexity of diseases. Rapidly advancing technology and the incorporation of genetic tests and other biomarkers into NBS will make it possible to detect many more genetic conditions (Solomon et al. 2012). Such tests will also pose challenges because many of these conditions are not well understood or treatable and will shift the implications and uses of NBS.

This raises an important question: "Are we ready for that expansion?" In this article, I will first discuss new tools such as genomics and metabolomics for newborn screening. I will then turn to assessing how best to take advantage of new technical developments while considering the best interests of patients and the success of newborn screening.

\section{METABOLOMICS}

Metabolomics is comprehensive analysis of the repertoire of biochemicals that are present in cells, tissues, and body fluids and represents individuals' overall health status (Nicholson and Lindon 2008). Metabolomic findings are influenced by the genome, diet, drugs, environmental factors, and the gut microbiome. The metabolic profile provides 
information about biochemical status ranging from normal physiology to pathology that may not be obvious from gene expression analysis (Fiehn 2002). The current newborn metabolic screening practice captures only a fraction of the information present in the metabolome and only measures a small set of biochemical markers that are mostly disease-specific (Chace and Kalas 2005, Rinaldo et al. 2008). Examples include measuring phenylalanine to detect patients with PKU or succinylacetone for screening of tyrosinemia type 1.

Metabolomics generally uses biofluids, cells, and tissues as the primary source of metabolic data. Urine, serum, and plasma are the most common biofluids since they can be easily obtained. Analysis of dried blood spots (DBSs) is the standard for NBS for IEM. The analysis of DBSs and urine spots has limited application in metabolic profiling at this point, but validation of this approach will come soon (Wilson 2011).

Current newborn metabolic screening targets certain metabolites such as amino acids and acylcarnitines, which are measured with tandem mass spectrometry (MS/MS). It also measures enzymes levels using either MS/MS for lysosomal storage diseases (LSDs) or other methods for biotinidase and galactosemia. Abnormal levels of each marker can point to (a) a single metabolic disease; (b) several different metabolic diseases; (c) maternal disease; or (d) other factors such as medication, prematurity, nutritional deficiencies, and a sick neonate.

Acylcarnitines are the markers for fatty acid oxidation defects and organic acidemias (Rinaldo et al. 2008). Abnormal acylcarnitine species indicates a single metabolic disease; several different metabolic diseases; or a false positive. For example, an elevated level of octanoyl carnitine (C8) points to MCAD deficiency. Elevated levels of 3-hydroxyisovaleryl carnitine (C5$\mathrm{OH})$ could be due to $\beta$-ketothiolase deficiency, biotinidase deficiency, holocarboxylase deficiency, 3-OH-3-methylglutaryl-CoA lyase (HMG-CoA lyase) deficiency, 2-methyl-3-hydroxybutyric aciduria (2M3HBA), 3-methylglutaconic aciduria (3MGA), or 3-methylcrotonyl-CoA carboxylase (3MCC) deficiency. To differentiate among all these possibilities, urine organic acid analysis, plasma acylcarnitine analysis, and/or genetic tests should be performed. Free carnitine (CO) is low in both primary (carnitine transport defect) and secondary (nutritional carnitine deficiency) carnitine deficiency. A confirmatory test (blood and urine carnitine levels, the genetic test for carnitine transport defect, or checking maternal carnitine levels) is essential to differentiate between these two causes. Medications may also cause falsely elevated levels of certain markers such as C5. Muscle tissue proteolysis, a hypoxic event during delivery, as well as hemolysis can also cause falsely elevated levels of acylcarnitine species such as $\mathrm{CO}$, propionylcarnitine (C3), or isobutyryl-/butyrylcarnitine (C4). The ratios of acylcarnitines species heighten suspicion for inborn errors of metabolism. For example in CPT 1 deficiency, both $\mathrm{CO}$ and $\mathrm{CO} /$ palmitoyl (C16)-stearylcarnitine (C18) ratios are elevated. On the other hand, hypoxia/muscle proteolysis may cause elevated $\mathrm{C} 0$ accompanied by normal C16-C18 ratio.

Amino acids are markers for amino acid disorders (Rinaldo et al. 2008). Elevated phenylalanine level and phenylalanine/tyrosine ratio, for example, indicate PKU. Several different metabolic diseases or nonmetabolic conditions can cause elevated amino acids. To give two examples, elevated methionine might indicate classical homocystinuria or methionine adenosyltransferase I/III (MAT I/III) deficiency or other factors such as prematurity or total parental nutrition (TPN). Elevated tyrosine could be due to tyrosinemia type I, II, III, transient tyrosinemia, nonmetabolic liver disease, or TPN.

\section{How Can Metabolomics Be Useful for NBS?}

Metabolomics is emerging as a key driver in the postgenomic landscape because of its tight relationship with phenotype, but it is still in its infancy with regard to the investigation of IEMs (Aygen et al. 2014; Miller et al. 2015; Tebani et al. 2016). Advances in metabolomics may provide predictive, prognostic biomarkers of disease state, help us to describe diseases more accurately, and allow for subclassifications of diseases detected through NBS. For 
example, psychosine has been studied as a marker that is found elevated in newborns with infantile onset Krabbe disease, but it is normal in cases who do not have the infantile form (Carter et al. 2016). The New York state NBS program is considering measuring psychosine level as a secondary test in newborns with low galactocerebrosidase enzyme activity (Krabbe disease). Hex4 is another marker that helps us to differentiate infantile-onset Pompe patients from late-onset cases (Manwaring et al. 2012).

\section{GENOMICS}

Whole-exome sequencing (WES) is analysis of all exons of all protein coding genes in the human genome. This technology is increasingly used in clinical practice (Bamshad et al. 2011; Majewski et al. 2011; Kaname et al. 2014; Fokstuen et al. 2016). WES analyzes about 30 million base pairs that are translated into functional proteins. Mutations in base pairs may impair protein expression or function, thereby causing disease. WES is a less costly and more efficient method in detecting mutations causing Mendelian diseases than whole-genome sequencing (WGS). However, WGS still is a useful and sometimes essential tool. WGS analyzes roughly 3 billion base pairs; it is more powerful than WES for detecting (a) singlenucleotide variants (SNVs) and (b) copy-number variants (CNVs) because it covers all breakpoints (Belkadi et al. 2015; Lelieveld et al. 2015). Belkadi et al. (2015) also showed that a large number of exons from protein-coding genes and noncoding RNA genes were not targeted by WES despite being fully sequenced by WGS.

WGS also detects variants in RNA and protein-coding regions that are not covered by the exome kit. The importance of variants in noncoding regions is not well understood (Ward and Kellis 2012), and it is difficult to interpret their relation and relevance to the phenotype of interest (Cooper and Shendure 2011).

Several recent publications spanning the United States, Canada, and Europe extensively discuss and provide recommendation for the implementation of WES in clinical care. The American College of Medical Genetics and Genomics (ACMG) republished recommendations for reporting of incidental or secondary findings unrelated to the indication for ordering the sequencing when WGS or WES is used in clinical practice (Kalia et al. 2016). The recommendations are based on available data and current experience and need annual updates based on rapidly increasing experience and data.

At present time WGS is much more expensive than WES because of two factors: (a) the higher relative cost of its sequencing technology and (b) its need for a more comprehensive infrastructure to store, manage, and analyze data. However, the sequencing technology for WGS has been improving at a very fast rate while reducing its costs. As the cost differential between WGS and WES diminishes, WGS will become the preferred clinical practice because it yields approximately 100 times more data than WES at the same coverage. This is a welcome development since WGS extends the variation search space to the whole genome and provides more uniform and better coverage depth and genotype quality (Belkadi et al. 2015).

What Are the Legal and Ethical Concerns of Next-Generation Genetic Tests in NBS? Using WGS or WES as a tool in NBS has multiple challenges including cost, feasibility, turnover time, reporting requirement, and legal issues. In the near future, some of these factors such as cost or turnaround time may be overcome. Flashpoints for legal and ethical issues include questions and conflicts around mandating WGS; the benefits and drawbacks to reporting all incidental findings; the need to get a full consent from parents/guardians for screening. Some contend that children should have the right to know-or not to know-their genetic information so that they can decide for themselves what information they want to know once they reach adulthood. Most of the vast amount of data produced by WGS will 
yield variants of unknown significance that could cause uncertainty and anxiety throughout their life (Lynch et al. 2010; Goldenberg and Sharp 2011; Tarini 2011).

\section{Can States Mandate WGS/WES-Based NBS?}

Each state has the authority to structure and operationalize newborn screening for its citizens. Currently, many state NBS programs mandate NBS. This is based on the 10th Amendment of the U.S. Constitution, which reserves rights to states not delegated to the federal government, such as the right to implement programs to protect the health and general welfare. States can mandate NBS for disorders for which early diagnosis saves lives. PKU is a very good example of this because patients with PKU do not have any symptoms in the first months of life, and once their symptoms are recognized, irreversible brain damage occurs and it is too late for treatment to prevent mental retardation. If they are detected through NBS and a low phenylalanine diet is started in the first weeks of life, they can enjoy normal development. A simple intervention (low-protein diet) can save PKU patients' lives if they are diagnosed in asymptomatic period through NBS. It makes sense for states to mandate for PKU. Many other IEMs have been added into NBS panels, many of them satisfy Wilson and Jungner criteria albeit not fully, but early detection and treatment improves outcomes in many of them.

There is also the other side of the coin. Based on the courts' interpretation of the 14th Amendment as safeguarding parents' rights to make medical decisions concerning their children, parents also have the right to consent to their child's medical procedures and treatment. States have strong claims to support mandated NBS for disorders such as PKU for which children have unquestionable benefits. This claim gets weaker when a test such as WGS or WES is used as a NBS tool that can provide a child's genetic characteristics and risks and detect many genetic conditions that are neither well-understood nor treatable at the present time. Only a small portion of the numerous genetic findings generated by WGS/WES-based NBS will be clinically significant. We must be mindful of the legal and ethical concerns raised by state-mandated intrusion on parents' autonomy in making decisions about their child's best medical interests. This extends to parents' right to decide not to use either WES/WGS to generate such extensive genetic information about their child (Gostin 2000; Mandl et al. 2002; Ross 2010; Tarini and Goldenberg 2012).

\section{What Are the Current Practices in Terms of Right to Opt Out of NBS or Requirement} for Informed Consent?

In current NBS practice in the United States, states differ significantly in terms of their requirements for (a) mandating NBS; (b) parents opting out of NBS, and (c) getting parents' informed consent. In three states, NBS is mandated and parents cannot opt out of NBS for any reason. In 30 states, parents may opt out of NBS based on religion. In 15 states, parents can opt of NBS based on personal reasons in addition to religion. Only two states, Maryland and Wyoming, require the parents' informed consent (Mandl et al. 2002).

NBS testing relies on testing performed on DBSs on filter paper. Several controversies have arisen in relation to their long-term storage and use for future research. These mostly revolve around the absence of consent at the time of NBS. This will undoubtedly become more exigent if and when WES/WGS will be used as a screening test. Future use of stored DBSs for population-based genomic studies raises a number of ethical, legal, and social challenges that involve public trust, privacy, and consent. It also may provoke broader ethical questions about the tension between the privacy rights of parents/individual children and the benefits to public health and future research justifying the practice of mandatory newborn screening (Tarini 2011). 


\section{CONCLUSION}

New investigative thinking is needed to transform genomics and metabolomics into NBS, while not forgetting the basic rules of Wilson and Jungner criteria.

WES/WGS will almost certainly generate many incidental findings that will compel state NBS programs carefully to distinguish between conditions that should—or should not-be reported out without parental consent. Mandatory screening should be preserved for disorders that meet the criteria of direct benefit to infants. Many disorders including creatine deficiency syndromes, Wilson disease, and metachromatic leukodystrophy that currently cannot be screened because of the lack of a reliable biomarker will be detected via WES/WGS-based NBS. Detecting these disorders, which are present in childhood and are treatable, have great direct benefits to infants and their families. Development of new biomarkers will provide core knowledge to shape clinical decisions, help newborn screened cases be defined and classified efficiently, and monitor treatment response more effectively.

NBS is a system, not a test. The addition of new tests to screening panels is taking place without the funding or infrastructure needed to provide adequate follow-up care and clinical services to newborns and their families. Concerns about access to treatment and long-term follow-up are not new in NBS. They may well become even more important issues when NBS is expanded using WES/WGS and other biomarkers. A lack of comprehensive insurance coverage for confirmatory tests and treatment is another concern. It is important to avoid conditions under which children who have undergone mandatory screening are left with a diagnosis but no resources and means to treat it.

It is important to clearly and effectively distinguish the imperatives of research from clinical practice when we use advanced tools such as genomics-WGS/WES - with or without metabolomics in NBS. Parents/guardians must recognize NBS for what it is: an important and effective public health measure to save individual babies' lives. The demands

Competing Interest Statement

The author has declared no competing interest. and goals of research must always be subordinated to and harmonized with this highest priority.

\section{REFERENCES}

AAP Newborn Screening Task Force. 2000. Serving the family from birth to the medical home-newborn screening: a blueprint for the future-a call for a national agenda on State newborn screening programs. Pediatrics 106: 389-422.

American College of Medical Genetics Newborn Screening Expert Group. 2006. Newborn screening: toward a uniform screening panel and system-executive summary. Pediatrics 117: S296-S307.

Aygen S, Dürr U, Hegele P, Kunig J, Spraul M, Schäfer H, Krings D, Cannet C, Fang F, Schütz B, et al. 2014. NMR-based screening for inborn errors of metabolism: initial results from a study on Turkish neonates. JIMD Rep 16: 101-111.

Bamshad MJ, Ng SB, Bigham AW, Tabor HK, Emond MJ, Nickerson DA, Shendure J. 2011. Exome sequencing as a tool for Mendelian disease gene discovery. Nat Rev Genet 12: 745-755.

Belkadi A, Bolze A, Itan Y, Cobat A, Vincent QB, Antipenko A, Shang L, Boisson B, Casanova JL, Abel L. 2015. Whole-genome sequencing is more powerful than whole-exome sequencing for detecting exome variants. Proc Natl Acad Sci 112: 5473-5478.

Carter RL, Wrabetz L, Jalal K, Orsini JJ, Barczykowski AL, Matern D, Langan TJ. 2016. Can psychosine and galactocerebrosidase activity predict early-infantile Krabbe's disease presymptomatically? J Neurosci Res 94 1084-1093.

Chace DH, Kalas TA. 2005. A biochemical perspective on the use of tandem mass spectrometry for newborn screening and clinical testing. Clin Biochem 38: 296-309.

Cooper GM, Shendure J. 2011. Needles in stacks of needles: finding disease-causal variants in a wealth of genomic data. Nat Rev Genet 12: 628-640. 
Ficicioglu C, Thomas N, Yager C, Gallagher PT, Hussa C, Mattie A. 2008. Duarte (DG) galactosemia: a pilot study of biochemical and neurodevelopmental assessment in children detected by newborn screening. Mol Genet Metab 95: 206-212.

Fiehn O. 2002. Metabolomics-the link between genotypes and phenotypes. Plant Mol Biol 48: 155-171.

Fokstuen S, Makrythanasis P, Hammar E, Guipponi M, Ranza E, Varvagiannis K, Santoni FA, AlbarcaAguilera M, Poleggi ME, Couchepin F, et al. 2016. Experience of a multidisciplinary task force with exome sequencing for Mendelian disorders. Hum Genomics 10: 24.

Goldenberg AJ, Sharp RR. 2011. The ethical hazards and programmatic challenges of genomic newborn screening. JAMA 307: 461-462.

Gostin L. 2000. Public health law: power, duty, restraint. University of California Press, Berkeley.

Janečková H, Hron K, Wojtowicz P, Hlídková E, Barešová A, Friedecký D, Zídková L, Hornik P, Behúlová D, Procházková $D$, et al. 2012. Targeted metabolomic analysis of plasma samples for the diagnosis of inherited metabolic disorders. J Chromatogr A 1226: 11-17.

Kalia SS, Adelman K, Bale SJ, Chung WK, Eng C, Evans JP, Herman GE, Hufnagel SB, Klein TE, Korf BR, et al. 2016. Recommendations for reporting of secondary findings in clinical exome and genome sequencing, 2016 update (ACMG SF v2.0): a policy statement of the American College of Medical Genetics and Genomics. Genet Med 19: 249-255.

Kaname T, Yanagi K, Naritomi K. 2014. A commentary on the promise of whole-exome sequencing in medical genetics. J Hum Genet 59: 117-118.

Lelieveld SH, Spielmann M, Mundlos S, Veltman JA, Gilissen C. 2015. Comparison of exome and genome sequencing technologies for the complete capture of protein-coding regions. Hum Mutat 36: 815-822.

Lynch E, Dezen T, Dewey LA. 2010. National standard for newborn screening is announced. March of Dimes. May 21. http://www.marchofdimes.com/aboutus/49267_65861.asp

Majewski J, Schwartzentruber J, Lalonde E, Montpetit A, Jabado N. 2011. What can exome sequencing do for you? J Med Genet 48: 580-589.

Mandl KD, Feit S, Larson C, Kohane IS. 2002. Newborn screening program practices in the United States: notification, research, and consent. Pediatrics 109: 269-273.

Manwaring V, Prunty H, Bainbridge K, Burke D, Finnegan N, Franses R, Lam A, Vellodi A, Heales S. 2012. Urine analysis of glucose tetrasaccharide by HPLC; a useful marker for the investigation of patients with Pompe and other glycogen storage diseases. J Inherit Metab Dis 35: 311-316.

Miller MJ, Kennedy AD, Eckhart AD, Burrage LC, WulffJE, Miller LA, Milburn MV, Ryals JA, Beaudet AL, Sun Q, et al. 2015. Untargeted metabolomic analysis for the clinical screening of inborn errors of metabolism. $J$ Inherit Metab Dis 38: 1029-1039.

Nicholson JK, Lindon JC. 2008. Systems biology: metabolomics. Nature 455: 1054-1056.

Paul DB. 1998. The history of newborn phenylketonuria screening in the US. Johns Hopkins University Press, Baltimore.

Petros M. 2012. Revisiting the Wilson-Jungner criteria: how can supplemental criteria guide public health in the era of genetic screening? Genet Med 14: 129-134.

Rinaldo P, Cowan TM, Matern D. 2008. Acylcarnitine profile analysis. Genet Med 10: 151-156.

Ross LF. 2010. Mandatory versus voluntary consent for newborn screening? Kennedy Inst Ethics J 20: 299-328.

Solomon BD, Pineda-Alvarez DE, Bear KA, Mullikin JC, Evans JP. 2012. Applying genomic analysis to newborn screening. NISC comparative sequencing program. Mol Syndromol 3: 59-67.

Tarini BA. 2007. The current revolution in newborn screening: new technology, old controversies. Arch Pediatr Adolesc Med 161: 767-772.

Tarini BA. 2011. Storage and use of residual newborn screening blood spots: a public policy emergency. Genet Med 13: 619-620.

Tarini BA, Goldenberg AJ. 2012. Ethical issues with newborn screening in the genomics era. Annu Rev Genomics Hum Genet 13: 381-393.

Tebani A, Abily-Donval L, Afonso C, Marret S, Bekri S. 2016. Clinical metabolomics: the new metabolic window for inborn errors of metabolism investigations in the post-genomic era. Int J Mol Sci 17: 1167.

Ward LD, Kellis M. 2012. Interpreting noncoding genetic variation in complex traits and human disease. Nat Biotechnol 30: 1095-1106.

Wilcken B. 2013. Newborn screening: gaps in the evidence. Science 342: 197-198.

Wilson I. 2011. Global metabolic profiling (metabolomics/metabolomics) using dried blood spots: advantages and pitfalls. Bioanalysis 3: 2255-2257. 


\section{COLD SPRING HARBOR Molecular Case Studies}

\section{New tools and approaches to newborn screening: ready to open Pandora's box?}

Can Ficicioglu

Cold Spring Harb Mol Case Stud 2017, 3: a001842

Access the most recent version at doi: $10.1101 / \mathrm{mcs} . a 001842$

References This article cites 32 articles, 3 of which can be accessed free at: http://molecularcasestudies.cshlp.org/content/3/3/a001842.full.html\#ref-list-1

License This article is distributed under the terms of the Creative Commons Attribution-NonCommercial License, which permits reuse and redistribution, except for commercial purposes, provided that the original author and source are credited.

Email Alerting Receive free email alerts when new articles cite this article - sign up in the box at the Service top right corner of the article or click here. 